\title{
Kinerja Perusahaan Modal Ventura Diukur dari Sisi Rasio Beban Operasi terhadap Pendapatan Operasi Rasio Investasi Terhadap Total Aset Return on Asset dan Non Performing Finance (Studi Kasus Pada PT. Sarana Jakarta Ventura)
}

Kartono ${ }^{1)}$

${ }^{1)}$ dosen Universitas Pamulang, email : tons kartono@yahoo.co.id

\section{ARTICLES INFORMATION}

ABSTRACT

\section{JURNAL SEKURITAS \\ (Saham, Ekonomi, Keuangan dan Investasi ) \\ Vol.3, No.2, Januari 2020 Halaman : $122-131$ \\ (C) LPPM \& Prodi Manajemen UNVERSITAS PAMULANG \\ ISSN (online) : 2581-2777 ISSN (print) : : 2581-2696 \\ Keyword : \\ Rasio Beban Operasi terhadap Pendapatan Operasi Rasio Investasi Terhadap Total Aset Return on Asset dan Non Performing Finance}

JEL. classification : C33, G21, G24, N15, N25

\section{Contact Author : \\ PRODI MANAJEMEN UNPAM \\ JL.Surya Kencana No.1 \\ Pamulang Tangerang Selatan - Banten \\ Telp. (021) 7412566, Fax (021) 7412491 Email : \\ sekuritas@unpam.ac.id}

Penelitian ini dibuat untuk mengetahui kinerja perusahaan yang diukur dari sisi rasio keuangan yang terdiri dari beban operasi terhadap pendapatan operasi (BOPO), Investment and financing to Asset Ratio (IFAR), serta mengetahui hasil evaluasi penilaian kinerja melalui Return on Asset (ROA). Pengukuran juga dilakukan dalam rangka menilai kesehatan pembiayaan perusahaan dilihat kualitas dari pencapaian pembiayaan atau non performing finance (NPF) selama periode tahun 2012-2019 sesuai dengan ketentuan Peraturan Otoritas Jasa Keuangan Nomor 35/POJK.05/2015 tentang Penyelenggaraan Usaha Perusahaan Modal Ventura tahun 2015. Objek penelitian ini adalah PT Sarana Jakarta Ventura dan Sampel penelitian ini dibatasi dengan menggunakan metode purposive sampling yang berjumlah hanya satu perusahaan sebagai kasus. Data yang digunakan dalam penelitian ini adalah data primer yang diperoleh dari laporan keuangan dalam periode 2012-2019. Hasil penelitian menunjukan tingkat pencapaian yang baik dilihat dari rasio BOPO, IFAR maupun dari sisi ROA namun dilihat dari aspek kesehatan kualitas pembiayaan ini dalam kondisi kurang sehat.

This research was made to find out the company's performance collected from the financial ratio consisting of operating costs to operating income (BOPO), Investment and financing to Asset Ratio (IFAR), as well as knowing the results of research on the performance improvement performance through Return on Assets (ROA). The assessment was also carried out within the framework of the company's financial assessment seen from the financing or financial performance (NPF) assessment for the period of 2012-2019 in accordance with the provisions of the Financial Services Authority Regulation No. 35 / POJK.05 / 2015 concerning the Implementation of Venture Capital Business Enterprises in 2015 The object of this study PT Sarana Jakarta Ventura and the sample of this study used a purposive sampling method that only supported one company as a case. The data used in this study are primary data obtained from the 2012-2019 financial statements. The results showed a good level seen from the ratio of BOPO, IFAR and in terms of ROA but viewed from the health aspect of financing quality in a less healthy condition. 


\section{A. PENDAHULUAN}

PT. Sarana Jakarta Ventura (Jakvent), didirikan tanggal 5 Februari 1998 "berpartisipasi turut melaksanakan dan menunjang kebijakan dan program pemerintah di bidang ekonomi dan pembangunan nasional pada umumnya dengan jalan menumbuhkan dan meningkatkan jiwa wiraswasta dan kemampuan berusaha pengusaha-pengusaha swasta nasional kecil dan menengah tanpa mengabaikan asas-asas berusaha sehat". Atau secara ringkas misi perseroan adalah "Membentuk usaha kecil dan menengah menjadi perusahaan yang tangguh dan mandiri". Bidang Usaha PT Sarana Jakarta Ventura sesuai dengan pasal 2 Peraturan Otoritas Jasa Keuangan No.35/POJK.05/2015, tentang Kegiatan Usaha Perusahaan Modal Ventura, dimana dijelaskan ada 4 (empat) kegiatan usahanya; "1) Penyertaan Saham, 2) Obligasi Konversi, 3) Pembiayaan pada Tahap Rintisan (Start Up) dan/atau pengembangan usaha, 4) Pembiayaan Usaha Produktif (PUP)".

Berdasarkan data dari Laporan Otoritas Jasa Keuangan periode triwulan IV-2018 terdapat satu pencabutan izin usaha Perusahaan Modal Ventura (PMV) sehingga jumlah Perusahaan Modal Ventura 65 perusahaan. Total aset, liabilitas, dan ekuitas Perusahaan Modal Ventura mengalami kenaikan masing-masing sebesar 3,35\%,5,18\%, dan 0,81\% menjadi Rp.11,75 triliun, Rp.6,97 triliun, dan Rp. 4,78 triliun dibandingkan triwulan sebelumnya. Total pembiayaan/penyertaan Perusahaan Modal Ventura mengalami kenaikan sebesar 4,89\% menjadi Rp8,46 triliun. Pembiayaan/penyertaan terbesar berasal dari pembiayaan bagi hasil dengan proporsi sebesar $77,45 \%$ dari total pembiayaan/penyertaan dengan nilai pembiayaan yang disalurkan sebesar Rp.6,55 triliun. Sementara itu, berdasarkan jenis sektor ekonomi, sektor perdagangan, restoran, dan hotel mendominasi total pembiayaan atau penyertaan yang disalurkan industri PMV dengan total pembiayaan/penyertaan sebesar Rp3,72 triliun atau sebesar 43,52\%.

Peningkatan pembiayaan tersebut, dibarengi penurunan rasio Non Performing Finance (NPF) atau kredit macet. Sampai Oktober 2018, industri modal ventura mencatatkan rasio NPF sebesar $5,24 \%$, jauh lebih rendah dari periode sama tahun lalu yang mencapai $7,08 \%$. Menurutnya, penyusutan kredit macet ditopang peningkatan pembiayaan sekaligus pelunasan kredit yang ikut melonjak.

Diperkirakan, trend pertumbuhan positif tersebut akan berlanjut sampai akhir tahun ini. Karena adanya insetif pajak dari pemerintah yang mendorong investor semakin nyaman berinvestasi di sektor ini. Selain itu, pemerintah juga menggagas program The Next Unicorn, sebagai program untuk melahirkan perusahaan startup potensial yang akan diorbitkan menjadi unicorn.

Perkembangan dan pertumbuhan Industri Modal Ventura yang terjadi saat ini mulai diberlakukannya Peraturan Otoritas Jasa Keuangan (POJK) Modal Ventura sejak tahun 2015, yakni:

1. POJK Nomor 34/POJK.05/2015 tentang Perizinan Usaha dan Kelembagaan Perusahaan Modal Ventura, pada Pasal 9 POJK No. 34/POJK.05/2015 tentang Permodalan, PMV harus memenuhi ketentuan permodalan untuk badan hukum perseroan terbatas pada saat pendirian harus memiliki Modal Disetor paling sedikit sebesar Rp 50 milliar.

2. POJK Nomor 35/POJK.05/2015 tentang Penyelenggaraan Usaha Perusahaan Modal Ventura, mengatur;

- Pasal 2 POJK No.35/POJK.05/2015, tentang Kegiatan Usaha PMV, dimana dijelaskan ada 4 (empat) kegiatan usahanya; Penyertaan Saham, Obligasi Konversi, 
Pembiayaan pada Tahap Rintisan (Start Up) dan/atau pengembangan usaha, dan Pembiayaan Usaha Produktif (PUP).

- Pasal 11 PMV diwajibkan memiliki penyertaan saham dan/atau obligasi konversi minimal $15 \%$ dari total kegiatan usaha PMV.

- Pasal 12 dalam POJK No. 35/POJK.05/2015 disebutkan Investment and Financing to Assets Ratio (IFAR) paling rendah $40 \%$.

- Pasal 33 bagi PMV yang berbentuk Perseroan Terbatas (PT) dan telah mendapatkan izin usaha sebelum POJK ini diundangkan sesuai Pasal 33 POJK No.35/POJK.05/2015 wajib memiliki Ekuitas paling sedikit sebesar Rp 20 milliar paling lambat 31 Desember 2020 dan paling sedikit sebesar Rp 50 milliar paling lambat tanggal 31 Desember 2025.

3. POJK Nomor 36/POJK.05/2015 tentang Tata Kelola Perusahaan Yang Baik Bagi Perusahaan Modal Ventura.

4. POJK Nomor 37/POJK.05/2015 tentang Pemeriksaan Langsung Perusahaan Modal Ventura

5. POJK Nomor 27/POJK.03/2016 tentang Penilaian Kemampuan dan Kepatutan bagi Pihak Utama Lembaga Jasa Keuangan

Dengan hadirnya POJK tersebut memberikan pengaruh kepada setiap Perusahaan Modal Ventura yang terdaftar di bawah pengawasan Otoritas Jasa Keuangan (OJK), perubahan ini berpengaruh secara korporasi dan menunjukkan arah yang jelas kembalinya Industri Modal Ventura kepada fungsi dan tujuan dan bentuk usaha modal ventura.

\section{B. KAJIAN LITERATUR}

\section{a. Pengertian Perusahaan Modal Ventura}

Menurut Keppres No. 61 tahun 1988, menguraikan tentang pengertian modal ventura sebagai berikut: "Modal ventura adalah badan usaha yang melakukan usaha pembiayaan dalam bentuk penyertaan modal ke suatu perusahaan yang menerima bantuan pembiayaan untuk jangka waktu tertentu"

Sejumlah penulis memberikan berbagai definisi tentang modal ventura, antara lain sebagai berikut:

Robert Wite menyebut "modal ventura adalah penyediaan pembiayaan untuk memungkinkan pembentukan dan pengembangan usaha-usaha baru, baik dibidang teknologi maupun non teknologi. la menitik beratkan usaha baru bidang teknologi dan non teknologi".

Tony Lorenz melihat segi risiko, capital gain, bunga dan deviden. "Modal ventura adalah investasi jangka panjang dalam bentuk pemberian modal yang mengandung risiko bagi penyedia dana atau perusahaan modal ventura terutama mengharapkan capital gain, bunga atau deviden".

Sedangkan menurut David Gladstone dan Laura Glastone tahun 2002 pada halaman 5 dalam bukunya yang berjudul "Venture Capital Handbook" menjelaskan sebagai berikut: "Venture capital investement is characterized by high risk"

Dan Christine Ammer dan Deans S. Ammer tahun 1984 halaman 96 dalam bukunya "Dictionary of Business and Economic" menjelaskan sebagai berikut:

"Venture Capital is Risk, or Venture Capital is Funds invested in an enterprise with alarge element of risk the owner or shareholders. Risk capital carries both a high profitabily or complete loss the investor and the potential for large return, as high as 1.000 to 5.000 percent. Most risk capitalist expect to earn a return, in five to ten years, at a rate that approximately doubles their original investement every 30 mounths or so" 
Dari definisi diatas dapat disimpulkan bahwa "modal ventura merupakan suatu penanaman modal pada suatu usaha yang memiliki karakter risiko yang cukup tinggi. Dimana risiko tersebut dapat memberikan keuntungan yang besar atau bahkan akan membuat kerugian yang besar pula. Kebanyakan risiko yang timbul adalah risiko pada tingkat pengembalian modal yang ditanamkan".

Banyak ahli memberikan konsep modal ventura yang berbeda-beda, "untuk lebih memahami tentang modal ventura tidak begitu sukar untuk menguraikan tentang apa itu venture capital dan membedakan mana venture capital dengan bukan venture capital. Pinjaman yang diberikan bank pada debitur itu adalah bukan venture capital, membeli saham atau obligasi yang dibeli di pasar modal itupun bukan ventura capital. Suatu perusahaan real estate melakukan investasi dengan membeli gedung apartemen, shopping centre dan sebagainya itu juga bukan venture capital. Jika ada anak perusahaan melakukan investasi pada suatu perusahaan kecil, hal ini dapat dikatakan sebagai venture capital".

\section{b. Fungsi Perusahaan Modal Ventura}

Wimar Witular dalam bukunya "Pandangan Venture Capital Dalam Pendanaan Program Inkubator", yang dikutip oleh KPHN Hoedhiono Kadarisman pada tahun 1995 halaman 144-145 dalam bukunya "Modal Ventura : Alternatif Pembiyaan Usaha Masa Depan", dapat dilihat dari empat hal yaitu sebagai berikut:

1. "Modal ventura merupakan modal saham yang disediakan sebagai: "risk capital" kepada seseorang atau suatu perusahaan yang mempunyai gagasan, tanpa jaminan pengembalian seperti halnya pinjaman. Dasarnya terutama keyakinan pada kekuatan gagasan seorang wirausahawan (entrepreneur). Risiko investasi dipikul oleh perusahaan modal ventura".

2. "Modal ventura bukan merupakan uang yang ditanamankan secara pasif. Pemasukan modal kedalam perusahaan klien oleh suatu perusahaan modal ventura disertai keterlibatan. Jika perlu, dalam unsur-unsur kunci yang dapat turut menentukan sukses usaha seperti manajemen keuangan, pemasaran dan pengawasan operasional".

3. "Berbeda dengan penanaman modal biasa, modal ventura dimasukkan kedalam suatu usaha untuk waktu sementara. Tujuannya adalah menarik kembali modal tersebut setelah usaha berjalan lancar, dengan cara penjualan kembali saham pendirian tersebut".

4. "Keuntungan modal ventura diharapkan datang dari apresiasi nilai saham tersebut atau capital gain, bukan dari bunga atau management fee. Tidak ada risiko beban di luar proporsi keuntungan perusahaan. Hal ini merupakan daya tarik modal ventura bagi pengusaha (entrepreneur)".

Karakteristik lain yang juga merupakan ciri khas dari modal ventura sebagaimana dikemukakan oleh Handoko Dipo tahun 1995 halaman 10 dan 11 dalam bukunya "Sukses Memperoleh Dana Usaha : Dengan Tinjauan Khusus Modal Ventura" disebutkan sebagai berikut:

1. Perusahaan modal ventura tidak hanya menginvestasikan modalnya, tetapi juga ikut terlibat dalam manajemen perusahaan yang dibantunya. Keterlibatan itu didasarkan pada kemampuan manajemen profesional atau adanya akses ke kontak bisnis (pemasok, pembeli, pemerintah, sumber dana lainnya dan sebagainya). Adanya kemungkinan keterlibatan inilah yang membedakan perusahaan modal ventura dengan lembaga pendanaan lainnya.

2. Perusahaan modal ventura bukanlah sejenis yayasan yang ingin beramal. Perusahaan modal ventura menginvestasikan dananya dengan mengharapkan keuntungan yang tinggi. Hanya dengan harapan akan keuntungan yang tinggi 
inilah perusahaan modal ventura mampu melakukan investasi pada usaha yang berisiko tinggi.

3. Perusahaan modal ventura yang profesional tidak berniat melakukan investasi yang permanen. Setiap kesempatan untuk mencairkan investasi dengan keuntungan yang baik akan dipertimbangkan oleh perusahaan modal ventura.

c. Rasio Beban Operasional terhadap Pendapatan Operasional

Rasio Beban Operasional terhadap Pendapatan Operasional (BOPO) "digunakan untuk mengukur perbandingan antara biaya operasional yang ditanggung apabila dibandingkan dengan pendapatan operasional yang mampu dihasilkan" rasio BOPO dirumuskan sebagai berikut:

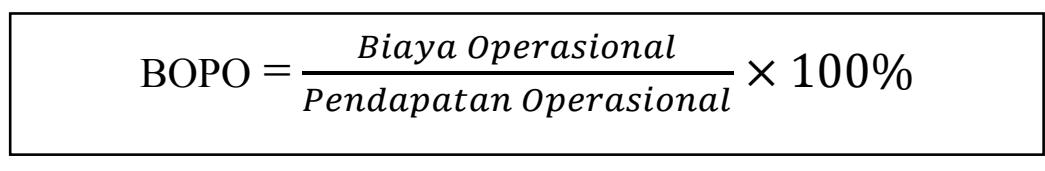

\section{Kriteria Peringkat BOPO}

\begin{tabular}{|l|c|l|}
\hline \multicolumn{1}{|c}{ Rasio } & Peringkat & \multicolumn{1}{c|}{ Keterangan } \\
\hline "BOPO $\leq 94 \% "$ & 1 & "Sangat Sehat" \\
\hline "94\% < BOPO $\leq 95 \% "$ & 2 & "Sehat" \\
\hline "95\% < BOPO $\leq 96 \% "$ & 3 & "Cukup Sehat" \\
\hline "96\% < BOPO $\leq 97 \% "$ & 4 & "Kurang Sehat" \\
\hline "BOPO > 97\%" & 5 & "Tidak Sehat" \\
\hline \multicolumn{2}{|c|}{ Sumber : "Surat Edaran BI No. 6/23/DPNP tahun 2004" }
\end{tabular}

\section{d. Rasio Investment and financing to Asset Ratio (IFAR)}

Aturan Peraturan Otoritas Jasa Keuangan (OJK) Nomor Pasal 12 dalam POJK No. 35/POJK.05/2015 "menetapkan investasi, penyertaan dan nilai piutang perusahaan atau disebut juga Investment and Financing to Assets Ratio (IFAR) ditetapkan minimal sebesar $40 \%$, atau UUS wajib memiliki nilai investasi, penyertaan, dan/atau nilai piutang yang berasal dari kegiatan usaha sebagaimana dimaksud dalam Pasal 2 ayat (1) dan/atau Pasal 6 ayat (1) huruf a terhadap total aset PMV, PMVS, dan/atau UUS yang selanjutnya disebut Investment and Financing to Assets Ratio (IFAR) paling rendah sebesar 40\% (empat puluh persen)". Rumus dapat dihitung sebagai berikut:

$$
\text { IFAR }=\frac{\text { Investasi }}{\text { Total Aktiva }} \times 100 \%
$$

\section{e. Return On Assets (ROA)}

Rasio ini digunakan untuk mengukur kemampuan manajemen bank dalam memperoleh keuntungan (laba) secara keseluruhan. "Semakin besar ROA suatu bank, semakin besar pula tingkat keuntungan yang dicapai bank tersebut dan semakin baik pula posisi bank tersebut dari segi penggunaan asset (Dendawijaya, 2005:118) dalam Mirdhani (2013)". "Besarnya nilai Return On Assets dapat dihitung dengan rumus berdasarkan Surat Edaran BI No. 6/23/DPNP tahun 2004" sebagai berikut:

$$
\mathrm{ROA}=\frac{\text { Laba sebelum Pajak }}{\text { Total Aktiva }} \times 100 \%
$$


Kriteria Peringkat Rentabilitas (ROA)

\begin{tabular}{|c|c|c|}
\hline Rasio & Peringkat & Keterangan \\
\hline "ROA $\leq 94 \% "$ & 1 & "Sangat Sehat" \\
\hline$" 1,25 \%<$ ROA $\leq 1,5 \% "$ & 2 & "Sehat" \\
\hline "O,5\% < ROA $\leq 1,25 \% "$ & 3 & "Cukup Sehat" \\
\hline "O\% < ROA $\leq 0,5 \% "$ & 4 & "Kurang Sehat" \\
\hline "ROA $\leq$ O \%" & 5 & "Tidak Sehat" \\
\hline
\end{tabular}

Sumber: "Surat Edaran BI No. 6/23/DPNP tahun 2004"

\section{f. Non Performing Finance (NPF)}

Kualitas Piutang Pembiayaan Bermasalah (Non Performing Financing) Neto menurut POJK No.35/P.5/2015 yang selanjutnya disebut "NPF Neto adalah piutang pembiayaan yang terdiri dari piutang pembiayaan dengan kualitas kurang lancar, diragukan, dan macet, setelah dikurangi cadangan penyisihan penghapusan piutang pembiayaan untuk piutang pembiayaan yang terdiri dari piutang pembiayaan dengan kualitas kurang lancar, diragukan, dan macet".

"PMV dinilai memiliki potensi kesulitan yang membahayakan kelangsungan usaha sebagaimana dimaksud pada ayat (1) jika memenuhi satu atau lebih kriteria":

1. "Rasio Kewajiban Penyediaan Modal Minimum (KPMM) sama dengan atau lebih besar dari $8 \%$ (delapan persen) namun kurang dari rasio KPMM sesuai profil risiko Bank yang wajib dipenuhi oleh Bank";

2. "Rasio modal inti (tier 1) kurang dari persentase tertentu yang ditetapkan oleh OJK";

3. "Rasio Giro Wajib Minimum (GWM) dalam rupiah sama dengan atau lebih besar dari rasio yang ditetapkan untuk GWM dalam rupiah yang wajib dipenuhi oleh Bank, namun berdasarkan penilaian OJK Bank memiliki permasalahan likuiditas mendasar";

4. "Rasio kredit bermasalah secara neto (Non Performing Loan/NPL net) atau rasio pembiayaan bermasalah secara neto (Non Performing Financing/NPF net) lebih dari $5 \%$ (lima persen) dari total kredit atau total pembiayaan".

Rasio Pembiayaan Bermasalah dihitung dengan formula:

$$
\mathrm{NPF}=\frac{\text { Pembiayaan Bermasalah }}{\text { Total Pembiayaan }} \times 100 \%
$$


Kriteria Peringkat (NPF)

\begin{tabular}{|c|c|c|}
\hline Rasio & Peringkat & Keterangan \\
\hline "NPF $\leq 7 \% "$ & 1 & "Peringkat" \\
\hline$" 7 \%<$ NPF $\leq 10 \% "$ & 2 & "Peringkat" \\
\hline "10\% < NPF $\leq 13 \% "$ & 3 & "Peringkat" \\
\hline "13\% < NPF $\leq 16 \% "$ & 4 & "Peringkat" \\
\hline "NPF > $16 \% "$ & 5 & "Peringkat" \\
\hline
\end{tabular}

Sumber : Surat Edaran POJK No.3 Tahun 2019

\section{METODOLOGI PENELITIAN}

\section{a. Ruang Lingkup Penelitian \\ Sifat Penelitian}

Menurut Sugiyono (2003) "Penelitian deskriptif, adalah penelitian yang dilakukan untuk mengetahui nilai variabel mandiri, baik satu variabel atau lebih (independen) tanpa membuat perbandingan, atau menghubungkan dengan variabel lain". Menurut Sugiyono (2003) terdapat pula penelitian kuantitatif, "Penelitian kuantitatif, adalah penelitian dengan memperoleh data yang berbentuk angka, atau data kualitatif yang diangkakan". Berdasarkan teori tersebut yang ada, maka penelitian ini merupakan penelitian yang bersifat deskriptif kuantitatif. Menurut Mudrajad (2007) dalam Hadiaroh (2013), "penelitian deskriptif kuantitatif menggunakan metode numerik dan grafis dalam mengenali sejumlah data, merangkum informasi yang tepat dalam data tersebut dan menyajikan data tersebut dalam bentuk yang diinginkan".

\section{b. Penentuan Populasi dan Sampel}

\section{Populasi}

Populasi yang digunakan dalam penelitian ini adalah PT. Sarana Jakarta Ventura sebagai kasus.

\section{Sampel}

Menurut Sugiyono (2003) pengertian sampel adalah "bagian dari jumlah dan karakteristik yang dimiliki oleh populasi tersebut". Teknik pengambilan sampel yang digunakan dalam penelitian ini adalah purposive sampling, dimana pengambilan sampel dilakukan berdasarkan kriteria tertentu yang ditentukan oleh peneliti.

\section{c. Metode Pengumpulan Data}

1. Studi Pustaka (Library Research), "pengumpulan data dengan studi pustaka adalah dengan membaca referensi yang mendukung isi penelitian ilmiah ini. Data yang diperoleh melalui studi pustaka adalah sumber informasi yang telah ditemukan oleh para ahli yang kompeten dibidangnya, data berasal dari buku, website, artikel yang berkaitan dengan pembahasan penelitian".

2. Dokumentasi, "mengumpulkan serta mencatat kembali data-data yang dimiliki perusahaan berkaitan dengan masalah yang akan dibahas dan yang akan dijadikan objek penelitian (Masri Singarimbun:1995) dalam Permata Sari (2006)".

\section{e. Sumber Data dan Jenis Data Penelitian}

Penelitian ini menggunakan data yang diperoleh secara langsung atau biasa disebut data primer. "Jenis data yang digunakan adalah data yang bersifat kuantitatif dan 
dikumpulkan dari waktu ke waktu untuk melihat perkembangan atau kecenderungan keadaan atau yang biasa disebut Time series".

\section{f. Metode Analisis Data Analisis Deskriptif}

Berikut adalah uraian langkah dalam menganalisis data secara deskriptif yang dimaksudkan untuk mendapatkan hasil pemeringkatan kesehatan bank/lembaga keuangan dari penelitian ini:

a. "Mencari rasio dan nilai kredit yang didapat dari perhitungan masing-masing faktor dan komponen berdasarkan perhitungan meliputi, BOPO, ROA, IFAR dan NPF".

b. "Membandingkan rasio-rasio selama periode 2013-2019 dengan kriteria penetapan peringkat yang mengacu pada Surat Edaran Bank Indonesia No. 6/23/DPNP tanggal 31 Mei 2004 dan POJK No.35/2015".

c. "Menginterprestasikan hasil perbandingan dalam menentukan peringkat komposit kesehatan Lembaga Keuangan Non Bank atau Modal Ventura dari masing-masing aspek penilaian".

d. "Melakukan evaluasi hasil perhitungan metode NPF untuk mendapatkan nilai kredit faktor secara keseluruhan dalam menentukan predikat kesehatan Perusahaan Modal Ventura".

\section{HASIL DAN PEMBAHASAN}

Berdasarkan tinjauan teoritis atas rasio-rasio yang menjadi evaluasi kinerja Perusahaam Modal Ventura yang digolongkan ke beberapa rasio sebagai alat ukur diataranya BOPO, ROA, IFAR dan NPF dalam pelaksanaan perundang-undangan yang berlaku sesuai POJK maka didapat hasil perhitungan sebagai berikut:

\begin{tabular}{|r|r|r|r|r|r|}
\hline No & Tahun & BOPO & IFAR & ROA & NPF \\
\hline 1 & 2012 & $86 \%$ & $61 \%$ & $2 \%$ & $34 \%$ \\
\hline 2 & 2013 & $91 \%$ & $83 \%$ & $2 \%$ & $17 \%$ \\
\hline 3 & 2014 & $52 \%$ & $73 \%$ & $6 \%$ & $57 \%$ \\
\hline 4 & 2015 & $133 \%$ & $62 \%$ & $-2 \%$ & $51 \%$ \\
\hline 5 & 2016 & $88 \%$ & $51 \%$ & $3 \%$ & $24 \%$ \\
\hline 7 & 2017 & $78 \%$ & $46 \%$ & $3 \%$ & $18 \%$ \\
\hline 8 & 2018 & $100 \%$ & $48 \%$ & $2 \%$ & $19 \%$ \\
\hline & 2019 & $91 \%$ & $45 \%$ & $2 \%$ & $27 \%$ \\
\hline & Average & $90 \%$ & $59 \%$ & $2 \%$ & $31 \%$ \\
\hline
\end{tabular}

1. Nilai rata-rata rasio BOPO periode $2012-2019$ adalah $90 \%$, "nilai rasio ini lebih tinggi jika dibandingkan dengan nilai standar rasio rentabilitas yang ditetapkan Bank Indonesia yaitu lebih besar dari $4 \%$, sehingga jika dilihat dari aspek rentabilitas dikategorikan dalam kondisi sangat sehat".

2. Nilai rata-rata rasio IFAR selama periode 2012-2019 adalah 59\%, "nilai rasio ini lebih tinggi jika dibandingkan dengan nilai standar rasio yang di harapkan menurut POJK No.35/POJK/2015. Kegiatan usaha perseroan telah menunjukkan beberapa pemenuhan POJK, pasal 12 POJK No. 35/POJK.05/2015 diharuskan Investment And Financing To Assets Ratio (IFAR) paling rendah 40\%, dimana rata-rata Perusahaan dalam pemenuhan IFAR rata-rata sebesar 59\%".

3. Kemudian berdasarkan nilai rata-rata rasio ROA selama periode $2012-2019$ adalah $2 \%$, "nilai rasio ini lebih tinggi $0,5 \%$ jika dibandingkan dengan nilai standar rasio rentabilitas yang ditetapkan Bank Indonesia yaitu kurang dari 1,5\%, sehingga jika dilihat dari aspek 
rentabilitas dengan rasio ROA rata-rata industri perbankan dan Lembaga Keuangan Non Bank dikategorikan dalam kondisi sangat sehat".

Nilai rata-rata rasio NPF selama periode 2012-2018 adalah $31 \%$, "nilai rasio ini lebih tinggi jika dibandingkan dengan nilai standar rasio yang ditetapkan Peraturan Otoritas Jasa Keuangan (POJK) yaitu maksimal sebesar $7 \%$, sehingga jika dilihat dari aspek Kesehatan Perusahaan Modal Ventura dikategorikan peringkat 5 (NPF > 16\%) atau dalam kondisi peringkat $5 "$.

\section{E. KESIMPULAN}

\section{Kesimpulan}

1. Dari pembahasan hasil analisis yang merujuk pada pokok masalah yang ada menunjukkan rasio-rasio pengukuran kinerja dari Perusahaan Modal Ventura khususnya PT Sarana Jakarta Ventura dalam periode 2012-2019 jika "dilihat dari aspek rentabilitas dalam kondisi sangat sehat, dari aspek kualitas aset dalam kondisi sehat, namun dievaluasi dari aspek tingkat kesehatan pembiayaan sebagai lembaga keuangan dinilai kurang maksimal".

2. Hasil evaluasi aspek secara menyeluruh "menunjukan dari ke-3 rasio perusahaan berada dalam predikat sehat, sehingga jika dilihat secara rata-rata dikategorikan dalam predikat cukup sehat".

\section{Saran}

1. Perusahaan Modal Ventura dalam hal ini PT Sarana Jakarta Ventura yang dianalisa dengan menggunakan tingkat rasio tersebut diatas mendapatkan predikat sehat, diharapkan untuk terus mempertahankan posisinya dengan meningkatkan kinerja pada berbagai aspek.

2. Sedangkan pada tingkat kesehatan kinerja Investasi/pembiayaan menghasilkan tingkat rasionya kurang maksimal dan mendapatkan predikat kurang sehat, dengan kondidi ini diharapkan agar dapat meningkatkan kinerjanya sehingga "dapat meningkatkan posisinya, terutama yang mengalami gejala-gejala atau indikasi yang tidak wajar agar terhindar dari potensi dan risiko dimasa yang akan dating".

3. Ditujukan kepada peneliti selanjutnya, "agar dapat mengembangkan penelitian ini dengan metode penilaian kesehatan bank/modal ventura lainnya, dengan cara menambah variable dan atau teknik yang berbeda".

\section{DAFTAR PUSTAKA}

"Undang-undang No.7 tahun 1992 Pasal 3 tentang Fungsi Utama Perbankan".

"Undang-undang No. 10 tahun 1998 tentang perubahan UU No. 7 tahun 1992"

Laporan OJK periode triwulan IV-2018

Budisantoso, Totok dan Sigit Triandaru. 2006. Edisi kedua. "Bank dan Lembaga Keuangan Lain. Salemba Empat. Jakarta".

Hadisoewito, Slamet. 1995. Prinsip Dasar Penilaian dan Kehati-hatian Bank. Radar Jaya. Jakarta

Kasmir. 2014. Edisi revisi. Bank dan Lembaga Keuangan Lainnya. Cetakan ke-14. PT Raja Grafindo Persada. Jakarta.

2015. Edisi revisi. Manajemen Perbankan. Cetakan ke-13. PT Raja Grafindo

Persada. Jakarta.

M. Sadeli, lili, 2002. Dasar-dasar Akuntansi. PT Bumi Aksara, Jakarta. 
Munawir. 1998. Edisi ke-empat. Analisa Laporan Keuangan. Cetakan ke-8. Liberty. Yogyakarta.

Sugiyono. 2003. Metode Penelitian Bisnis. Cetakan kelima. CV Alfabeta. Bandung.

Usman, Husaini. 2014. Edisi Keempat. Manajemen Teori, Praktik dan Riset Pendidikan. Cetakan Kedua. Bumi Aksara. Jakarta.

Van Horne, James C dan John M. Wachowicz, JR. 2009. Fundamentals of Financial Management $12^{\text {th }}$ Edition. Diterjemahkan oleh : Dewi Fitriasari dan Deny Arnos Kwary. 2009. Prinsip-prinsip Manajemen Keuangan. Salemba Empat. Jakarta.

Sunardi, N. (2017). Determinan Intelectual Capital dengan Pendekatan iB-VAIC ${ }^{\text {TM }}$ Terhadap Efisiensi Biaya Implikasinya Pada Profitabilitas Perbankan Syariah di Indonesia. JIMF (Jurnal IImiah Manajemen Forkamma), 1(1).

Sunardi, N., \& Sasmita, A. S. (2019). Pengaruh Likuiditas, Leverage Dan Growth Terhadap Kinerja Industri Makanan Dan Minuman Yang Tercatat Di Indonesia Stock Exchange Selama Periode Tahun 2011-2015. Jurnal Sekuritas (Saham, Ekonomi, Keuangan dan Investasi), 2(2), 81-97.

Lutfi, A. M., \& Sunardi, N. (2019). Pengaruh Current Ratio (Cr), Return On Equity (Roe), Dan Sales Growth Terhadap Harga Saham Yang Berdampak Pada Kinerja Keuangan Perusahaan (Pada Perusahaan Manufaktur Sektor Makanan Dan Minuman Yang Terdaftar Di Bursa Efek Indonesia). Jurnal SEKURITAS (Saham, Ekonomi, Keuangan dan Investasi), 2(3), 83-100.

Sunardi, N. (2018). Analisis Economic Value Added (Eva), Financial Value Added (FVA) Dan Market Value Added (MVA) Dengan Time Series Approach Sebagai Alat Penilaian Kinerja Keuangan (Studi Pada Industri Konstruksi (BUMN) di Indonesia Yang Listing di BEI Tahun 2013-2017). Jurnal SEKURITAS (Saham, Ekonomi, Keuangan dan Investasi), 2(1).

Abdul Kadim, K., \& Nardi Sunardi, S. (2018). Determinant Of Company's Likuidity And It's Implications On Financial's Performance Of Ritail Trade Company's In Indonesia At The Period Of 2008-2017. Global and Stockhastic Analysis, 5(7), 235-247.

"POJK Nomor 34/POJK.05/2015 tentang Perizinan Usaha dan Kelembagaan Perusahaan Modal Ventura",

"POJK Nomor 35/POJK.05/2015 tentang Penyelenggaraan Usaha Perusahaan Modal Ventura",

POJK Nomor 36/POJK.05/2015 tentang Tata Kelola Perusahaan Yang Baik Bagi Perusahaan Modal Ventura.

POJK Nomor 37/POJK.05/2015 tentang Pemeriksaan Langsung Perusahaan Modal Ventura.

POJK Nomor 27/POJK.03/2016 tentang Penilaian Kemampuan dan Kepatutan bagi Pihak Utama Lembaga Jasa Keuangan.

Sunardi, N. (2019, January). Relevansi Struktur Kepemilikan Tentang Profitabilitas Dan Nilai Perusahaan (Studi pada Industri Manufaktur yang Terdaftar di Bursa Efek Indonesia Periode 2010-2017). In Proceedings (Vol. 1, No. 1).

Bank Indonesia. 2004. "Surat Edaran Bank Indonesia No. 6/23/DPNP Tentang Sistem Penilaian Tingkat Kesehatan Bank Umum. Jakarta. 31 Mei 2004".

Bank Indonesia. 2004. "Peraturan Bank Indonesia No. 6/10/PBI/2004 Tentang Sistem Penilaian Tingkat Kesehatan Bank Umum. www.bi.go.id. 12 April 2004".

Bank Indonesia. 2011. "Surat Edaran Bank Indonesia No. 12/11/DPNP/2010. Tentang Penilaian Kesehatan Bank Umum. Jakarta”. 